\section{中国设计教育探索: \\ 从课堂到工作坊 \\ THOUGHTS ON \\ DESIGN EDUCATION IN CHINA: FROM CLASSROOM TO WORKSHOP}

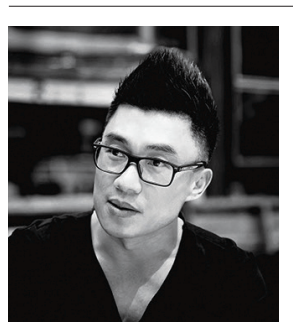

何志森

Mapping工作坊创始人, 华南理工大学建筑学院教师, 澳大利亚 墨尔本皇家理工大学建筑与城市设计学院兼任教授

广东省广州市天河区五山路381号华南理工大学建筑学院,

邮编: 510641

Jason.ho2@rmit.edu.au

Jason HO

Founder of Mapping Workshop; Lecturer, School of Architecture, South China University of Technology; Adjunct Professor, School of Architecture and Design, RMIT University

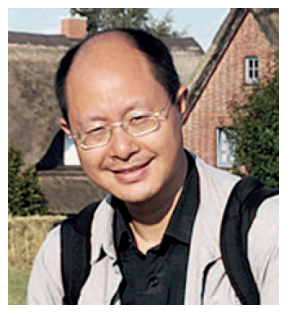

李迪华

北京大学建筑与景观设计学院副教授、景观设计学研究院副院 长, 《景观设计学》期刊执行主编

北京市海淀区顾和园路5号, 邮编: 10087

dihuali@pku.edu.c

\section{Dihua}

Associate Professor of College of Architecture and Landscape, and Vice Dean of Graduate School of Landscape Architecture, Peking University; Executive Chief Editor of Landscape Architecture Frontiers

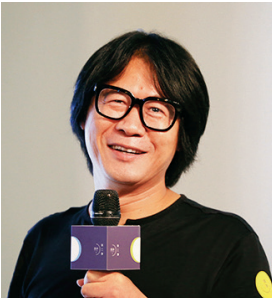

刘悦来

同济大学建筑与城市规划学院景观学系教师, 上海四叶草堂青少

年自然体验服务中心理事长

上海市杨浦区赤峰路63号8号楼701室，邮编：200092

liuyuelai@gmai1.com

LIU Yuela

Lecturer, Department of Landscape Architecture, College of Architecture and Urban Planning, Tongji University; President of Clover Nature School in Shanghai

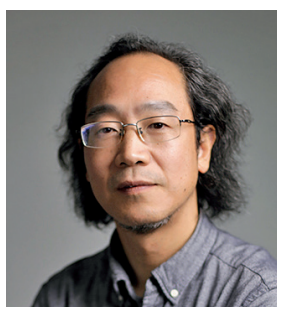

汪原

华中科技大学建筑与城市规划学院教授、博士生导师, 《新建 筑》杂志副主编

湖北省武汉市洪山区珞喻路1037号，邮编：430074

wangyuan@hust.edu.cn

WANG Yuan

Professor and PhD Supervisor of School of Architecture and Urban Planning, Huazhong University of Science and Technology; Associate Editor of New Architecture

注: 按照姓氏拼音首字母排序

NOTE: In alphabetical order of the authors' last names. \begin{tabular}{l|l} 
https://doi.org/10.15302/J-LAF-20180508 & $\begin{array}{l}\text { 采访时间 INTERVIEWED DATE / 2018-07-22 } \\
\text { 中图分类号 / TU2, TU986, G64 }\end{array}$
\end{tabular}

文献标识码/
摘要

作为2018全国学生校园营造联盟暑期Mapping\&Making工作坊的特 邀指导教师, 北京大学李迪华、Mapping工作坊创始人何志森、同济大学 刘悦来和华中科技大学汪原尝试为中国传统设计教学模式注入新的思路。 在访谈中，4位老师表达了自己对目前中国设计学科的教育体制和教学环 境的看法。他们一致认为, 中国设计教育已经面临着现实危机, 不论是高 校教师还是学生都需要意识到改变的迫切性; 目前设计教育改良尚未得到 足够重视, 学校间、教师间对于教育意义、教育未来的讨论尚未建立。他 们试图以工作坊教学为契机, 让高校师生们看到设计教育的更多可能, 同 时培养学生的观察力、探索欲、好奇心、自信心和独立思考及实证能力。 关键词

设计教育；教育危机；启蒙；教学法；批判

\section{ABSTRACT}

Li Dihua from Peking University, Jason Ho, Founder of the Mapping Workshop, Liu Yulai from Tongji University, and Wang Yuan from Huazhong University of Science and Technology were guest instructors at the 2018 Mapping \& Making Summer Workshop of National College Student Campus Building Alliance. They each work on bringing new ideas to traditional design education. In this interview they shared their opinions on current design education and teaching in China. They believe that design education in China is currently at a point of crisis where both instructors and students need to be aware of the urgency to change. However, little attention has been given to the improvement of design education, nor has a discourse to explore a future direction been built. The interviewees approached the workshop as an opportunity for students and educators to see new possibilities in design education. Meanwhile, they hope to develop students curiosity and confidence in observation, exploration, independent thinking, and evidential design.

Design Education; Educational Crisis; Enlightenment; Pedagogy; Criticism

整理 汪默英 余依爽 由玲于

译 曹若曦萨拉. 雅各布斯

EDITED BY WANG Moying SHE Yishuang RAN Lingy

TRANSLATED BY CISY CAO Sara JACOBS 
引言

2018年7月18 23日，2018全国学生校园 营造联盟暑期Mapping\&Making工作坊在北京大 学展开。除邀请到19位不同职业背景的导师进 行讲座交流外, 工作坊还选取了北京大学万 柳公寓中心花园作为基地, 在导师的指导下 进行场地研究及设计建造。由北京大学李迪 华、Mapping工作坊创始人何志森、同济大学 刘悦来和华中科技大学汪原共同组成的特邀 导师团队, 在提出问题、构想方案、讨论修 改、设计建造等阶段全程跟进指导。在工作 坊期间, 《景观设计学》对4位老师进行了采 访, 试图了解他们对于当前设计教育现状的 观察、体会和展望。

您认为目前国内设计学科的教育体制和 教学环境存在哪些主要问题?

汪原 (以下简称汪) : 中国学生最大的 问题是在家庭和学校间两点一线的生活中, 失去了与真实世界产生联系的机会。设计教 育的根本在于教会学生通过 “设计” 去认识 世界、认识城市、认识生活, 如果不了解生 活、不了解人, 何谈去做设计, 何谈去创造 环境或改变环境? 所以, 我认为学生人学后 的首要目标是要弥补之前缺失的人文教育, 但这在我们现行的设计教育体制中是严重缺 失的。大多数高校都要求学生直接投人到专 业训练之中, 把设计变为了一种遵循套路的 职业训练。学生们习惯以套路来应对问题, 却缺乏改变现实的渴望或冲动。如果连这种 最基本的冲动都没能激发, 我们的教育首先 就失败了。

刘悦来 (以下简称刘)：我认为问题不 仅出现在教育体制之内, 还在于我们所生活
的环境。在快速城镇化的影响下, 学生们从小 便与自然疏远，除了失去了感知真实世界的机 会外，我们在城市中感受到的 “自然” 很多都 是被设计过、改变过的, 政府、开发商所推崇 的 “四精” ——精确定位、精准设计、精致施 工、精美呈现一一设计遍布城市的各个角落。 但这种经过我们精心设计的城市对孩子们而言 可能恰恰是一种缺失一一在 “自然” 被矫正和 修饰、被精准化后, 生活在其中的人们也无从 感知其本真的自由的秩序。这种精致的技术美 一旦成为全社会的追求，每个人都将被训练得 讲求效率，更容易被培育成为 “精致利已主义 者”。我非常欣赏燕京大学校训 “因真理, 得 自由, 以服务” 所传达的价值观, 这也是我认 为的设计教育乃至所有教育的宗旨。

何志森（以下简称何）：我们对建筑的 认知是相对狭险的, 仿佛只有教科书的内容 才是唯一的准则, 鲜有人来探索建筑的可能 性一一无论是我主持的Mapping工作坊, 还是 汪原老师关注的 “电影建筑学” , 在很多高校 设计教育中都是比较边缘化的。但是大学不就 是要引导学生看到各种可能性么? 除了人文教 育和自然启蒙的缺失外, 我认为专业启蒙也还 远远不够。比如, 我和李迪华老师在 “一席” 上的演讲引起了广泛争议, 有人认为我们是在 博取眼球，但其实我们所做的就是最基本的专 业启蒙。与Mapping工作坊相类似的培训在国 外可以说是最基本的课程之一, 没想到竟在国 内引起了这么大的关注一一当大家把Mapping 工作坊当成一个话题进行讨论, 就证明我们 今天的建筑认知是有一定问题的。汪原老师说 过, “希望工作坊能让学生回到孩提时代, 找 回那时的创造力和好奇心, 以及对世界末知的 观察力和探索欲”。但其实中国的启蒙教育从 幼儿园起就已经缺乏了, 这些问题也一直延续 到了大学。
李迪华 (以下简称李) : 与社会隔离的 现象不止发生在大学以前的应试教育阶段, 在当今的许多大学也依旧存在。现在有很多 学校都建在市郊或乡村地区, 并且多采用封 闭式管理。一到周末，学生们就会像疯了似 的全部涌向城市, 去体验一个周末的城市生 活。那我们的学校为何不能直接建在闹市里 呢? 过去由于土地经济, 这些真正能够培养 人的品格的地方都被房地产所占用, 并通过 土地置换的方式到郊区占领一个更大的校 园。教育真正做得好的学校一定是在闹市之 中, 因为思想产生于与人的交流之中。

当前设计教育面临着怎样的危机, 您最 大的担忧是什么?

汪：我认为危机在于大家并没有看到危 机, 或是没有形成改变的意识。中国经济本 就忽冷忽热, 加之中美贸易战的影响, 我估 计 5 年内很多建筑师可能会找不到工作。设 计院关门, 房地产垮台, 甚至连老师都可能 失业。如果这些都将发生, 我们还要按现在 的套路去教学生如何建房子么? 建筑教育应 该取消还是另辟蹊径? 建筑高等教育在所有 高等教育学科中的立足之地何在? 而现在的 建筑教育人员却鲜有人思考这些问题, 各种 大会也会刻意回避这个背景, 这是十分危险 的。设计的主题本身就是改变—通过改变 来让我们的生活环境变得更好。如果作为设 计教育者的我们连教育本身的问题都不愿意 思考, 那我们如何能改造更大范围的制度或 环境?

李：其实不用等到 5 年后, 现在已有一 些事实在证明设计学科的危机。过去清华大 学建筑学院一直都是全校高考招分最高的 院系, 去年首次出现了净转出 16 个学生的现 
象, 这种情况已经不止在清华这一所高校发 生。这种现象到底会带来多大的反思, 我真 的没有把握一一现实情况是, 没有反思, 甚 至不允许反思。有的学校允许老师罔顾事实 地批判别的学校的教授, 却不允许自己学校 的专业、师生、校友受到批判, 甚至有人会 特别关注网络上的言论, 一旦自己学校受到批 评, 就组织人群起而攻之。对于这些学校来 说, 他们一直想做的事情似乎就是通过坚守错 误来排除异己。我们这些 “异已分子”已经成 为了对 “权威”、对套路的挑战。但我相信越 是批评我们的人, 未来越有可能成为我们的支 持者, 因为批评源于他们意识到了自己内心的 冲突, 一旦他明白这个冲突的解决方案在系统 之外，他们就会开始探索新的方向。

何: 我觉得大家对教育的问题其实都 心知肚明。在网络媒体如此发达的今天, 我们都很清楚国外的高校开展了哪些课 程或活动, 也更能够意识到国内外设计教 育体系的差距。但每当各个高校聚在一起, 讨论的问题往往无关痛痒、一团和气。现在 的问题在于, 很多人都意识到教育已经出现 问题, 但都宁愿睁一只眼闭一只眼, 或者直 接否定、排外，为不同立场的人扣上 “叛经 离道” “误人子弟” 的帽子。如果总是观念 相同的老师碰撞交流，意义其实并不大。我 希望能够与批判我们教学方式的老师产生 对话, 共同直面设计教育的问题所在和未 来方向。

身为高校教师, 您希望从哪些方面推动 改变? 或者您已经做过哪些尝试?

何：我们4位老师一起在做的这个工作坊 就是一种对好奇心、观察力、创造力的再激
发, 我们推翻传统的评分标准, 从人性、创 新力和语言表达能力三个方面来评判学生的 作品。我们想告诉学生们, 即使你不画一张 图, 也可以学习到专业知识技能。虽然现在 大多数学生仍处在一种消极的状态中, 很多 学生明知数十年如一日的教学方法已无法应 对不断变化的时代需求, 却只求尽快毕业、 出国求学, 而不愿推动改变。但我相信至少 那些来参加我们工作坊的学生还是想要有所 改变的, 毕竟这些课程没有学分, 还需要付 出路费和时间。很多老师也认为我们的教学 方式很有意义, 但他们的困扰在于怎么申请 基金, 怎么在核心期刊上发表文章, 怎么评 职称, 于是只能用现实那些残忍的东西去打 消掉心中的理想。所以我认为与其寄望于老 师主动改变, 不如思考学生如何通过自我改 变来推动老师进行转变。

刘: 我坚信教育体制一定是可以被改变 的。首先我们自己要乐观, 而且要积极投人 行动。只有在行动的过程中, 我们才会对问 题有更深刻的理解, 或是看到改变的希望所 在。这种行动可以是带学生做实习, 也可以 是去大众媒体平台上演讲。如果你不站出来 做事, 总是躲在后面, 就连改变的前提都不 具备了, 哪怕这样做会遭到很多人的批判。 我一直致力于社区花园的设计和营造, 是希 望能够改变以 “四精” 为主流的景观空间生 产方式。从公众做起, 让他们意识到自然野 趣和低成本设计的魅力, 并缓慢推动政府的 改变; 从小孩子抓起, 以启蒙教育影响他们 今后的价值观、择业观。除活动、科普外, 我们团队也在尝试着写总结性的文章来发表 专业论文、申请基金和申报奖项。想要有一 定的影响力, 光靠我们 “自烸” 肯定是不够 的, 只有获得更多评审机制的认可, 使更多
实实在在的项目落地, 并努力去引领行业未 来的方向, 才能逐渐在现有机制上实现一定 的突破。

李: 我一直在努力做一个不去教学生 的老师, 甚至有时在做一个 “破坏者”。现 在的学生有很多通病, 比如缺乏好奇心和自 信心: 一方面, 他们害怕表达自己, 担心自 己说错; 另一方面, 他们也抵制和排斥别人 有与自己不同或相反的观点。结果把时间浪 费在权衡各种想法之中, 只不断提出问题, 却不愿着手弄明白。再比如学术神圣化: 好 像自己不提出个问题、不谈点理论, 就不是 学术。实际上, 学术源于对所关注问题的真 实状况的理解, 不少人从始至终都在探讨着 假问题, 意义何在? 这些习惯以套路应对问 题的学生在脱离套路后, 就开始恐惧, 唯恐 自己成为异类。学生的这些顽固的想法成为 他们进步的阻碍, 必须先破坏掉。设计教育 就是要尊重多样性, 培养学生追求与众不 同, 并把自己的想法做到极致。有的人来北 大读书可能只是需要一个 “光环” , 但北大 与众不同的地方在于我们要启发思想, 激发 自创, 虽然这条路无比艰难。学生只有陷人 思想的困惑、矛盾、纠结, 才会开始反思到 底为什么来北大读书, 到底要学些什么, 而 老师的作用就是协助学生进行重建, 从破坏 者变成支持者。我们一直在寻找改变的突破 口, 鼓励学生自我发现, 并且已经取得了一 定成效。学生一旦拥有自我发现的机会后, 他们的观念就会开始改变。LAF 


\section{Introduction}

In July 2018, the Mapping \& Making Summer Workshop of National College Student Campus Building Alliance was held at Peking University. Nineteen instructors from various professional backgrounds gave lectures and seminars on the innumerable layers of design. The Wanliu Apartments Community of Peking University was chosen as the site for investigation, design, and construction. The guest instructors team including Li Dihua from Peking University, Jason Ho, Founder of the Mapping Workshop, Liu Yulai from Tongji University, and Wang Yuan from Huazhong University of Science and Technology, provided instruction and suggestions for students throughout the workshop. Landscape Architecture Frontiers interviewed the four instructors, and they shared their observations and experience during the workshop, and their expectations for Architecture, Urban Planning, and Landscape Architecture education in China.

\section{What are the primary issues facing design education system and teaching environment in China?}

\section{WANG Yuan (WANG hereafter):}

The biggest issue for Chinese students is the loss of real world opportunities as they shuttle between family and school day after day. Spatial design is about knowing and interacting with the world, the city, and the life we encounter. If students do not understand their own life or the life of those around them, how can they change or create new environments? This should be the first lesson for every university student. They need to make up for what is missing from their liberal education. However, most universities put students into professional practice without any preparation or training. Students are continuing to use conventional strategies to solve design problems rather than exploring new methods and possibilities with inspiration and enthusiasm. If they lose their passion for design, our job as educators fails from the start.

\section{LIU Yuelai (LIU hereafter): In}

my opinion, the problem is not only educational environments, it is also our living environments. People lose their relationship with nature in rapidly urbanizing cities. On one hand, we have not spent enough time with nature. On the other hand, the "nature" we experience has been designed and constructed by humans. Landscapes that are defined accurately, designed sophisticatedly, constructed precisely, and presented delicately can be found everywhere. However, these welldesigned, sophisticated cities can also be a kind of deficiency for children they do not provide the unmodified or intrinsic ordering of nature. In a society that highlights a delicate artificial beauty, everyone would be trained to be highly efficient and become a sophisticated egoist. I believe that Freedom Through Truth For Service, the motto of Yanching University, should be the fundamental purpose of education.

Jason HO (HO hereafter): Our understanding of Architecture is relatively narrow. In higher education we are trained to follow precedents, other possibilities in architecture are rarely explored. The Mapping Workshop I led and the "Movie Architecture" studio that Professor Wang Yuan developed exist at the margins of university education. Is it not the job of universities to guide students towards greater possibilities? The lack of liberal education and nature enlightenment were already mentioned, but I think we are also far from professional enlightenment. For example, the speeches by Professor Li Dihua and me on "YiXi" brought controversy, but what we did is just for professional enlightenment. We did not expect the Mapping Workshop, which is a required course in other countries, would cause such a controversy in China. It exactly mirrors the deficiency when we viewing Architecture. Professor Wang had mentioned that he hoped the Workshop could encourage curiosity and creation, and the power of observation and exploration which are the natural qualities of every student. We realize that creative and analytical education has been lacking since kindergarten and continued to be an issue in China's higher education.

LI Dihua (LI Hereafter): The social isolation we are discussing about is not occurring only at exam-orientated schools, it is prolific and cannot be easily 
solved even at universities. Nowadays university campuses often sit in rural areas and are closed to surrounding communities. On the weekends, students rush downtown to experience city life. So why are we not building our universities in more urban areas? The answer is land value: universities have traded their downtown lands with real estate developers and build their campuses in more rural areas. I believe we need to locate our universities in urban areas where students can receive both social and academic education, since social education is essential for enlightenment and inspiration.

\section{What is your biggest concern about} the problems facing design education?

WANG: The largest problem is that people do not realize there is a problem. Today Chinese economy fluctuates, plus there is the impact of the US-China Trade War. I am guessing that a lot of architects will not be able to find jobs in the next five years. Design institutes will close, real estate will collapse, teachers may even lose their jobs. If this happens, will the discipline of Architecture be required? Or will we find a new path? What role does Architecture play in the future among all the disciplines of higher education? It feels risky that so few people in design education are thinking about these issues and that people deliberately avoid discussing about these issues. Design is about making our living environments better through change. If we cannot talk about the issues within our own education systems, how can we begin to talk about larger or broader changes?

LI: It will be less than five years before Architecture and other design disciplines go into a low period. In the past, the Department of Architecture of Tsinghua University has been a popular department with the best students. Last year there are sixteen undergraduate students who changed their major from Architecture, which has never happened before. Yet, this was not unique to Tsinghua. Will this bring more reflection to the education? I am not sure. The reality is that there is no reflection. Some universities allow their instructors to criticize other universities, while never accepting negative comments upon themselves. They extremely care about the comments online and are always ready to fight back. These universities are often opinionated and exclude the dissidents. We are the "dissidents" who challenge "authority" and the conventional design strategies. However, I believe those who criticized us may also be our supporters. They criticized because of their awareness of an inner conflict. Once they identify the conflict from an external standpoint, they will start to explore new paths.

HO: I think everyone knows the issues of design education. Thanks to Internet and social media, we are all aware of the courses or activities sponsored by universities around the world. We also realized the gaps between
China's design education system and that of foreign universities. However, when educators from Chinese universities get together, we always avoid these issues. And at a point, it is also meaningless if everyone shares the same opinions. The main problem is, though, that many of us have realized there are deficiencies or gaps within the current education, but most people would rather stay quiet. Some of them even exclude and regard people who hold different opinions are "rebellious" or "harmful to the younger generation." I hope to get feedback and advice from someone who is critical of our teaching methods. I want us to face the problem and challenge of design education together.

\section{What strategies might university instructors use or what have you done to} promote the change you are describing?

HO: The four of us are using the Mapping \& Making Workshop to re-inspire the curiosity, observation, and creativity of our students. We are abandoning the traditional standard and trying to evaluate students' work from humanity, innovation, and expression. We are demonstrating that students can learn expertise apart from drawing training. Most students, however, are stuck in negative ways of thinking and refuse to promote change even though they are aware of the limits of the old teaching methods. But, I believe that the students who come to our workshops are eager to change (because these courses are offered for no credits, and students 
still must pay and find the time for the classes). While many instructors may find our methods useful, they still worry about how to apply for funds, publish, or get promoted through scholarship. Such worries discourage them from making change. Instead of expecting the instructor to initiate change, it is better for students to think about how they can engender curriculum changes and in turn promote instructors' reflections.

LIU: I firmly believe that the education system is able to be changed. We must be optimistic and act. Only through action will we have a deeper understanding of the problem or see the possibility of change. We should be taking students on field trips, or trying new means of education, such as giving speeches on social media platforms. When you stand out, you risk being criticized but it is also how change happens. I have been working on the design and construction of community gardens in order to challenge the prevalent "precise design" fashion. I want to let the public be aware of the charm of wild nature and low-cost design and slowly accumulate to governmental change. I want to affect the future values and career choices of younger generations through enlightenment. At the same time, our team is trying to write and publish a series of papers and apply for funds and professional awards. We need more people to promote the change by trying to gain broader professional recognition, building up more practical projects, and leading the future direction.
In doing so we will gradually reform our educational system.

LI: I consider myself not as a teacher but a "destroyer" to break student's rigid way of thinking. The lack of curiosity and self-confidence is common among students. They worry about expressing themselves and saying the wrong thing while excluding alternate opinions. As a result, time is wasted by asking questions rather than trying to solve problems.

Another example is the misunderstanding about academic activities saying that it is simply about raising questions or talking about theories. In fact, academic opinions stem from our understanding of realities. If we keep discussing a fake question, there is no purpose to the discussion. Students who use conventional design strategies are afraid of new ideas, limiting themselves to develop forward. But design education needs to respect different views, help foster new ideas, and offer approach to transform the idea to an outcome. Students may study at Peking University because of its reputation but studying at Peking University is also about inspiring ideas and creation. When students are confused or contradictory, they begin to think more about why they are at Peking University. We, instructors, then are expected to support and help students in reconstruction. We are looking for the approach to change by encouraging students to discover their creative possibilities - we already have achieved some good results. Once students can discover themselves, they will accept new types of ideas and concepts. LAF 